\title{
Imagery determination of commitment to the country as part of the socio-psychological capital of the personality of students
}

\author{
Svetlana Frolova* \\ National Research State University named after N. G. Chernyshevsky, 410012, Saratov, \\ Russia
}

\begin{abstract}
The article contains the results of theoretical analysis and empirical research of imagery determination of students personality commitment to their country. The commitment of a personality to the country is considered in line with the theory of psychological relations of the personality, actively developed in modern social psychology, and within the framework of the concept of socio-psychological capital of the personality, proposed by A. N. Tatarko. The purpose of this article is to analyse the role of subjective images of the past, present and future of the country in building personality's commitment to the country. To achieve this goal, an empirical research was conducted, which was attended by 207 University students (125 women and 82 men) aged 18 to 23 years, all citizens of Russia. The research was conducted in compliance with the principle of anonymity of participation and using the author's fact-finding questionnaire "Commitment to their country", the developed imageryassociative test "The Image of Russia and Foreign Countries" and colour relations test. As a result of the study it was found out that subjectively constructed, positively significant images of the future of the country play the most important role in the formation of students' commitment to their country.
\end{abstract}

Personality's commitment to the country as a special socio-psychological attachment and desire to live within a certain socio-geographical community [1] are undergoing significant transformation in the modern mobile world. The cult of economism [2], the novelty of impressions, the rapid pace of life affect the change of human relations with various objects of social space, making them less stable and certain. Life prospects in the subjective views of modern people can be built in the space of socio-geographical communities of different countries. These transformations are largely facilitated by the emergence and development of global identity and virtual social communities. Under the conditions of macro-social transitivity the relevance of studying the phenomenon of personality's commitment to the country, its predictors and functions increases. There appear problems of scientific

\footnotetext{
*Corresponding author: frolovasv71@,mail.ru
} 
forecasting of natural processes of transformation of human relations with large macrosocial objects, one of which is the social community of the country.

The main thing is that the commitment of the personality to the social object lies in his intention and desire to continue to maintain with the social object the established connections that are manifested in social behaviour, social feelings and socio-cognitive representations. Commitment to the social object has such characteristics as future orientation, intentionality and potential readiness for a certain social behaviour, which gives reason to refer it to such a class of mental phenomena as psychological relations. The works of V.N. Myasishchev, who identified psychological relations as an independent class of mental formations that play the role of the inner strength of the personality, able to determine the content of its experiences and guide its future behaviour, were of great importance for the development of the theory of psychological relations [3]. The theory of psychological relations continues to be actively developed in modern social psychology [4] and becomes the methodological foundation for the creation of new areas of research. One of these areas is formed by the provisions of the concept of socio-psychological capital of the personality introduced by A.N. Tatarko. Socio-psychological capital of the personality is understood as a system of socio-psychological relations to the society as a whole and to its individuals and groups, which can be used to achieve various life goals [5]. This kind of personal capital can enter into various relations with the social, financial, cultural, human capital of the society. According to A.N. Tatarko, the socio-psychological capital of the personality becomes the individual basis of social capital and the well-being of the society as a whole [5].

The concept of socio-psychological capital is, as noted by A.N. Tatarko, an "umbrella" concept covering a wide range of socio-psychological relations [5]. The concept of personality's commitment to the country is a more specific concept that describes the phenomenology of one of the essential components of the socio-psychological capital of the personality. Under the commitment of the personality to the country we understand a special terminal (covering the entire perspective of human life, not a separate situation) personal relation (attitude) to the social community of the country, expressed in the desire and intention to build their future life within it, in attachment to its cultural, social and natural-geographical objects, in the ideas of the prospects of its spiritual and material resources to meet their leading needs. In the structure of the personality's commitment to the country, the conative component, responsible for the willingness to carry out social behaviour that would ensure the implementation of the long-term life strategy of their future within their country, is essential. One of the important functions of the personality's commitment to the country is to ensure the social and psychological adaptation of the personality.

The commitment of the personality to the country, as a component of the sociopsychological capital of the personality, obviously, can be formed as a result of the entire individual history of human life. Student age is not only a stage of professional knowledge acquisition, but also a life period when the foundation of all types of individual capital, including social and psychological capital, is being actively formed. Planning of the student's professional self-realization after graduation can be determined not only by objective, socio-economic and regional circumstances of life, but also by the system of personal relations to himself and to the world, the individual specificity of the formation of commitment to the country.

One of the important tasks in the study of the personality's commitment to the country is to reveal the laws of its origin, development and specificity of determination. The development of the personality's commitment to the country can be closely linked to the development of the human system of ideas about the world and about the opportunities and resources of his future within the country. The formation of such ideas can be laid at a very 
early age thanks to the imaginative forms of reflection and experience that accompany the cognitive development of a person at the earliest levels of pre-conceptual thinking. The concept of the image sphere of a person, developed by A.A. Gostev can be considered the initial theoretical and methodological basis for the consideration of the significance of images in the construction of social relations and social behaviour of the personality. The image sphere of the personality is understood as a multilevel system of secondary images (i.e. images of representation arising in the absence of the stimulus-object acting at the present time), including specific images of previously perceived objects, generalized images of various aspects of the surrounding world, subjectively constructed images of reality, etc. [6]. The emergence and construction of any image of perception and representation, as it was thoroughly shown by S.D. Smirnov, is characterized by the activity of the person himself [7].

The purpose of this article is to analyse the role of subjective images of the past, present and future of the country in building student personality's commitment to the country. We suggested that the subjective images of the past, present and future of the country can be used as predictors of student personality's commitment to the country. We also suggested that subjective perceptions of the future of the country play the most decisive role in building personality's commitment to the country. The logical basis for this assumption was one of the main, essential properties of the personality's commitment to the country its orientation towards the future. This orientation is expressed in a person's desire to build his future life within this particular country, based on the faith in its future.

\section{Sampling and research methodology}

To achieve this goal and test the proposed hypothesis, we conducted an empirical research using the following psychodiagnostic tools: 1) we have developed a questionnaire "Commitment to the country" [8], which allows to measure the severity of personality's commitment to the country; 2) imagery-associative test "The Image of Russia and Foreign Countries" [8], which serves to identify significantly experienced images of the country, including the images of the historical past of the country and images of the future of the country; 3) colour relations test by A.M. Etkind [9], used to study the features of the experience of the subjective generalized image of the country in the present.

As a dependent variable in our study, we analysed the variable "commitment of a personality to the country" (measured by a quantitative scale from 0 to 136 points). The variables "positive significance of the image of the historical past of the country" and "positive significance of the image of the future of the country" (measured using a quantitative scale from -10 to +10 points), "negative significance of the image of the country in the present time" (measured using a quantitative scale from 0 to 68 points) were analysed as independent variables.

The processing of the data of the test of colour relations to the country was carried out by establishing an absolute difference of ranks between the first three and the last three (as the most significant) selected colours in two rows of colour choices, one of which corresponded to personal and situational colour preferences, and the other - the experiences arising in connection with the represented image of the country. In order to take into account the strength of the emotional significance of the chosen colour while expressing the attitude to the country, a position significance coefficient was introduced, similar to the calculation of the level of anxiety in the methodology of M. Lüscher [10]: for the first and eighth (last) positions, the coefficient equalled three, for the second and seventh positions two, and for the third and sixth positions, as less significant, the coefficient was one. 
Evaluation of the role of subjective images of the historical past, present and future of the country in the formation of personality's commitment to the country was carried out by the method of multiple regression analysis performed using the computer program SPSS 20 .

The sample consisted of 207 University students (125 women and 82 men) aged 18 to 23 years (average age 20 years), all citizens of Russia. The research was conducted anonymously, which allowed removing unnecessary anxiety of respondents and creating conditions for more spontaneous and sincere responses and reactions to the proposed stimulus material of tests and questionnaire.

\section{Research results and their discussion}

Empirically obtained data were processed using the regression analysis method. Modified R-squared value for multiple regression model (see table. 1) indicates that $70 \%$ of the variance of the variable "commitment of the personality to the country" is determined by the combined effects of the variables "positive significance of the image of the future of the country", "the negative significance of the image of the country at the present time", "the positive significance of the image of the historical past of the country". In this case, the participation of the variable "negative significance of the image of the country in the present time" is of the opposite character (see table. 2).

Table 1. The statistical-mathematical indicators of the model of the complex imagery determination of the personality's commitment to the country

\begin{tabular}{|l|l|c|c|c|}
\hline \multicolumn{1}{|c|}{ Model } & R & R-square & $\begin{array}{l}\text { Modified } \\
\text { R-square }\end{array}$ & $\begin{array}{l}\text { Statistical } \\
\text { significance }\end{array}$ \\
\hline $\begin{array}{l}\text { Dependent variable: commitment to the country. } \\
\begin{array}{l}\text { Predictors: 1) positive significance of the image } \\
\text { of the future of the country, } \\
\text { 2) negative significance of the image of the } \\
\text { country in the present time, }\end{array}\end{array}$ & 0,840 & 0,705 & 0,701 & 0,000 \\
$\begin{array}{l}\text { 3) positive significance of the image of the } \\
\text { historical past of the country. }\end{array}$ & & & & \\
\hline
\end{tabular}

When considering the shares of each of the predictors of the personality's commitment to the country (see table. 2) the most significant determinative role of subjective images of the future of the country is revealed, as evidenced by the corresponding indicator of the standardized beta coefficient $(0,564$ at $\mathrm{p}=0.000)$, which takes the highest values among all independent variables. Almost $56 \%$ of the variance of the variable "commitment of the personality to the country" is determined by the impact of the variable "the positive importance of the image of the future of the country". The more positive is the subjectively constructed image of the future of the country, the more pronounced the commitment of the personality to the country is.

Table 2. Regression coefficients for the dependent variable "the personality's commitment to the country"

\begin{tabular}{|l|c|c|}
\hline \multirow{2}{*}{ Independent variable } & The standardized coefficients & $\begin{array}{c}\text { Statistical } \\
\text { significance }\end{array}$ \\
\cline { 2 - 2 } & Beta & 0,000 \\
\hline $\begin{array}{l}\text { 1) positive significance of the image of the } \\
\text { future of the country, }\end{array}$ & 0,564 & 0 \\
\hline
\end{tabular}




\begin{tabular}{|l|c|c|}
\hline $\begin{array}{l}\text { 2) negative significance of the image of the } \\
\text { country in the present time, }\end{array}$ & $-0,419$ & 0,000 \\
\hline $\begin{array}{l}\text { 3) positive significance of the image of the } \\
\text { historical past of the country. }\end{array}$ & 0,043 & 0,262 \\
\hline
\end{tabular}

For $42 \%$ of the sample, the variance of personality's commitment to the country is determined by the change in subjective experiences of the country's images in the present time. The less negatively the personality experiences the generalized image of the country in the present, the more expressed his desire to build its future within his country is (the value of the standardized beta coefficient is equal to $-0,419$; see table. 2 ).

Images of the historical past of the country do not have such a significant impact as the images of the present and future of the country. Only for $4,3 \%$ of the sample variance of the variable "commitment of the personality to the country" depends on the variable "subjective images of the historical past of the country." Apparently, this fact testifies in favour of intentionality, turning to the future and potential resourcefulness of such a component of social and psychological capital as the commitment of the personality to the country.

In addition to the quantitative expression and modality of the significance of the images of the historical past and future of the country, their qualitative analysis was additionally undertaken. We were able to establish that the images associated with the future of the country are predominantly ( $88 \%$ of the sample) generalized and accompanied by a description of their brightness/darkness, clarity/ambiguity, certainty/uncertainty, emotional attractiveness/unattractiveness. High values of personality's commitment to the country are usually accompanied by optimistic, bright images of the future of the country, which cause pleasant feelings; low rates of commitment to the country are more associated with uncertain, vague, frightening, ambiguous images of the future of the country or even with their absence.

It was found that the subjective images of the historical past of the country are filled with specific content more often than the images of the future of the country. The specific content of images of the historical past of the country is present in $66 \%$ of the respondents of the entire sample. However, the specificity of the content of images associated with the historical past of the country is more represented in persons with a high level of commitment to the country ( $72 \%$ of this subgroup of persons) than in persons with a low level of commitment to the country (38\% of the subgroup with a low level of commitment to the country). More specific fullness of images of the historical past of the country for those who plan to stay within their country can be a consequence of their better knowledge of the history of the country as well as a higher subjective significance for them of the historical past of their country.

Unexpectedly, we found out that $60,4 \%$ of the students who took part in the research, have a similar content of specific subjective images of the historical past of the country. This content is related to the themes of war, military action, victory in World War II. Only for $10,4 \%$ of the students surveyed specific subjective images of the historical past of the country are associated with phenomena and achievements in the field of culture. The dominance of the theme of war in spontaneous associations with the historical past of the country can be due to the great power of the emotional significance of the images of war, associated shocks, the scale of the tragedy, radically changing the fate of the entire nation. Perhaps such a heroic and at the same time tragic emphasis on the historical past of the country reinforces the desire to see the future of the country in more positive and bright colours. One way or another, but the commitment of the personality to the country becomes more closely related to how positively significant the images of the future of the country constructed by the personality are. 


\section{Conclusion}

The conducted research has generally allowed us to confirm the hypothesis that the predictors of personality's commitment to the country are constructed subjective images of the past, present and future of the country. It was also in studies revealing that subjective perceptions of the future of the country play the most decisive role in building personality's commitment to the country. The revealed feature allows us to show the importance of one of the essential properties of the personality's commitment to the country - its focus on the future, contributing to the implementation of its functions such as programming, regulation of social behaviour and building a life strategy of the personality.

The constructed images of the future of the country to the greatest extent, in comparison with the images of the present and the past of the country, depend on the content and degree of activity of the subject himself, his ability to interpret the perceived information and to comprehend the reality of life. The orientation of the person to the future has the greatest transformational potential for self-development in comparison with the focus on the experience of images of the past and present. The major determinative role of subjectively constructed images of the future of the country allows us to state in addition to the external, sometimes manipulative, impact on the personality of the broadcast screen and media images of the country, the existence of the possibilities of internal self-determination of the personality in the process of consciously building a psychological attitude to their country.

The features of subjective cognitive-imagery determination of the personality's commitment to the country can be taken into account in solving the problems of social and psychological adaptation of the personality, the experience of internal conflicts in the process of building life prospects and the complexities of the development of social and psychological capital of the personality of students.

\section{References}

1. A.A. Gostev, Psikhologiia vtorichnogo obraza (Publ. Institut psihologii RAN, Moscow, 2007)

2. A.L. Zhuravlyov, V.P. Poznyakov, Psihologicheskij zhurnal. 39 (5), 59-68 (2018)

3. A.N. Tatarko, Social'no-psihologicheskij kapital lichnosti v polikul'turnom obshchestve (Publ. Institut psihologii RAN, Moscow, 2014)

4. P.J. Buchanan, State of emergency. The third world invasion and conquest of America Edge of destruction (Thomas Dunne Books / St. Martin's Press, New York, 2006)

5. S.V. Frolova, Izv. Saratov Univ. (N.S.). Ser. Philosophy. Psychology. Pedagogy. 13 (4), 80-86 (2013)

6. S.V. Frolova. Social'no-kognitivnye osnovanija psihologicheskoj priverzhennosti svoej strane (Akademicheskij proekt, Moscow, 2017)

7. Shapar' V.B., Shapar' O.V. Prakticheskaya psikhologiya. Proektivnye metodiki (Feniks, Rostov-on-Don, 2006)

8. Smirnov S.D. Psikhologiya obraza: problema aktivnosti psikhicheskogo otrazheniya (Publ. MGU, Moscow, 1985)

9. Sobchik L.N. Metod tsvetovykh vyborov - modifikatsiya vos'mitsvetovogo testa Lyushera (Rech', St.Petersburg, 2016)

10. V.N. Myasishchev. Psihologiya otnoshenij (Publ. Moskovskij psihologo-social'nyj institut, Moscow, 2003) 